\title{
Environmental and Farmer's Managerial Characteristic Effect toward Production and Technical Efficiency on Rice Farm in Yogyakarta, Indonesia
}

\author{
Triyono $^{1}$, Jangkung Handoyo Mulyo ${ }^{2,3}$, Masyhuri ${ }^{2}$, and Jamhari ${ }^{2}$ \\ ${ }^{1}$ Departement of Agribusiness, Faculty of Agriculture, Universitas Muhammadiyah Yogyakarta, Indonesia \\ ${ }^{2}$ Departement of Agricultural Economic, Faculty of Agriculture, Universitas Gadjah Mada, Indonesia \\ ${ }^{3}$ Center for Population and Policy Studies (CPPS) Universitas Gadjah Mada, Indonesia
}

\begin{abstract}
The program of increasing food security by improving the productivity of farm production especially rice production through technology use and innovation face significant problem related to the land decreasing and quality of environmental and natural sources support. The study was aimed to identify technical factor, managerial, and environmental factor which influenced production and efficiency of rice farm production in Yogyakarta Special Province. The survey was conducted to rice farmers in rice field areas in $\mathbf{2 5}$ points of research location from 8 rivers those are the main sources of the irrigation system in Yogyakarta Special Province area. Data analyzing used stochastic frontier production function by inserting inefficiency effect model to identify determining factors of rice production as well as influential factors of rice farm production efficiency. The result showed that the land and total pesticide had positive influent toward rice production. Also, the farmer's experience and the availability of credit access can increase the technical efficiency of rice farm production. The improvement of irrigation facility and irrigation water quality control became an important environmental issue that should get significant attention.
\end{abstract}

Keywords- Efficiency, Managerial, Environment

\section{INTRODUCTION}

Sustainable agriculture becomes a crucial issue in developing countries as well as in under developing countries. It is significant especially in under developing countries since natural resources and technologies are limited. Those under developing countries have to struggle in increasing agricultural production to fulfill the increasing needs of the people. There are a lot of studies done to increase agricultural production through the improvement of farming efficiency based on resources and the existence of technologies. Several empirical studies have been made to measure the efficiency and sustainability of agriculture in a lot of countries.

People's investment to increase farming sustainability needs a proper assessment from farmers' efficiency and resource's identification that is no longer efficient to develop policies and innovations to minimize inefficiency [1].

Rice production sustainability can be created by measuring the efficiency on the level of farmer's effort, identifying the factors related to production efficiency, and formulating the policies for future use. As an alternative to increasing production output is an effort that is can be done by improving the technical efficiency. Technical efficiency means to produce by using more efficient resources [2]. Moreover, the increase of the income through efficiency improvement will give a description that farmers can increase it with the limit of existing resources. Thus, the efficiency of using resources will be an important bench mark in the developing farmer's effort sustainability in supporting food resilience and independence.

Technical efficiency is a relative measurement of farmer's managerial capability on the level of the existence of technology. It means that it happens due to the improvement of technical skill and farmer's. According to Van Passel [3], it correlates with age, education both formal and informal, experience, access to training, credit, and market.

In the study conducted in 2007, al[4]. Used published data between 1979 until 2005. It obtained 167 efficiency studies. The most dominant commodity that became the object of the studies was rice, and then it was followed by cow milking, and the whole farming efforts. In the study, horticulture studies were relatively limited only around $2 \%$ of the all studies.

A lot of studies have correlated the influence of social factor, economic factor, and ecological factor toward technical efficiency. There are some positive influence toward technical efficiency. They are farmer's age, education, access to training, access to credit, agro-ecology, farming area, per seal numbers owned by the farmers, family numbers, gender, renting, access to the market, and access to technology 
(fertilizer, pesticides, tractor, seeds, government's intervention) [5]; [6]; [7]; [8].

Bozoglu and Ceyhan [9] analyzed technical efficiency of vegetable production in Turk by using SFA approach. The determinants which determine technical efficiency include farmer's age, experience, education, family size, nonfarm income, dummy of credit, women participation, and information score. The result showed that the mean of technical efficiency was 0.82 . The main sources causing influencing technical efficiency was farmer's age. However, experience, education, credit use, women participation, and information score have the negative mark and have obvious influence toward technical efficiency.

In further, Abedullah et. al. [10] used stochastic frontier production function to determine the strategy of increasing rice production in Punjab. The result of the analysis showed that pesticide did not influence significantly to rice production. On the other hand, fertilizer had the negative impact toward productivity due to no precise composition of $\mathrm{N}, \mathrm{P}$, and $\mathrm{K}$. It indicated lack dissemination of training and counseling service. Therefore, counseling institution should empower to increase rice production as well as to protect significant natural resources and water sources for further generations. Nevertheless, the study had not analyzed the factors of natural sources especially water irrigation.

Meuya et. al. [11]. they conducted a study aiming to estimate the level of technical efficiency from 233 corn farmers in Tanzania by using stochastic frontier production to analyze influencing factors which played significant role on inefficiency, so there would be some ways to increase the production of wheat farmers with small scale in Tanzania. Technical efficiency varied from 1.1 percent until 91 percent of the average of TE $=60.6$ percent. The factors which had negative influence toward technical efficiency included low education, no credit access, capital limitation, area fragmentation, no availability of the input, and the high price of it. Farmers who have nonfarm income were found to be more efficient, and farmers who used chemical pesticides were not in using those for their farming production.

Bakhsh and Hassan [12] see the correlation between technical efficiency and managerial capability. Their study of the carrot farmers analyzed them. Education level and the openness on training service were influential factors toward technical efficiency. Thus, education improvement and wider training and counseling can increase technical efficiency and can reduce too many resources usage.

Obare et. al. [13] conducted a study to explore the level of resources allocation efficiency from potato farmers and to see influential factors on allocative efficiency. The result showed that experience, access to credit, access to training and counseling, membership in particular groups had positive and significant influence toward allocative efficiency. Hasan and Islam [14] used cross section data from three areas in Bangladesh and used Cobb-Douglas production function approach. The study concluded that education and training had significant influence toward technical inefficiency.
The studies related to efficiency by using technical factors and economical social factors as variables which had influence toward efficiency still dominant. There were only a few studies discussing environmental factors such as water irrigation, planting season related to weather or seasonal condition, and social, economic factor like land ownership status. There is not commonly discussion those variables in analyzing the efficiency of farm production. There are many cases with the factors in developing countries and tropical areas that can conduct farming production along the year with changing weathers and seasons. Therefore, this article presents a new thing there were not studies it before.

The effort of rice productivity improvement in Java Island as the supplier of 60 percent of national food production in Indonesia that is conducted through technology innovation face several problems. Those are mainly on reducing land areas and reducing fertility of it due to the use of chemical substances intensively causing soil pollution, water pollution, unhealthy living environment, and decreasing human health. The development of industrial, service, and property sectors in the era of economic development have given pressure on agricultural sector especially rice fields. Thus, intensive program becomes a significant factor to increase the production. The intensive program aims to increase the productivity is improvement of efficiency or technological breakthrough. In the condition of remaining technology, the efficiency improvement is the most proper effort to increase productivity.

Rice farm production center in Yogyakarta extends in Sleman and Bantul Regencies. Geographically, both areas have different characteristics. Farming areas in Sleman Regency are located in the northern Province of Yogyakarta which is relatively close to irrigation sources; however farming areas in Bantul are located in southern part of the province which is risky to pollution.

Rice production and productivity in Yogyakarta shows fluctuation during 2009 - 2013. The production improved significantly in 2012 with 12.25 percent. Its happened due to productivity and the increase of harvesting areas. On the other hand, in 2013 rice productivity significantly decreased although the areas increased [15]. That condition would influence on efficiency and sustainability of rice farm production in Yogyakarta.

Based on the problem above, there should be a comprehensive study related to technical factors, managerial characteristics, and environment toward rice production and efficiency of rice production in Yogyakarta.

\section{METHODS}

The study was conducted in Yogyakarta focused on the regencies which have the largest farming areas namely Sleman Regency and Bantul Regency. Sleman and Bantul Regency have more than 67 percent of the total rice farm in Yogyakarta. Besides, both regencies also have different agroecosystem based on the distance to irrigation sources. Sleman Regency is located in the upper course close to the irrigation 
sources. On the other hand, Bantul Regency is located in the downstream and far from the irrigation sources.

The river flow of the irrigation which is flowing Sleman and Bantul Regency and having pollution value based on the result of analysis of Environment Bureau of Yogyakarta becomes a base for the determination of sample taking location. From eight rivers flowing in both regencies, we determined the location in upper course, middle areas, and downstream with 25 points of sample taking location. We took five farmers each sample location as the samples with simple random sampling technique. Therefore, the numbers of the samples in the study are 125 farmers. We took the data of farm production in rainy planting season, and dry planting season in $2014 / 2015$, so the total observation amount 250 .

To analyze technical efficiency, the study used Stochastic Frontier Analysis (SFA) as the model. The model is used to estimate frontier production function. Production function is technical correlation between input used and output produced. Therefore, rice production function is directly influenced by the land of rice farm, total seeds, total labour, total N, P, and organic fertilizer, total pesticide, and the level of irrigation pollution. The specification of the model used as follow:

Ln $Y_{\text {it }}=\beta_{0}+\beta_{1} \ln X_{1}+\beta_{2} \ln X_{2}+\beta_{3} \ln X_{3}+\beta_{4} \ln X_{4}+\beta_{5} \ln X_{5}+$ $\beta_{6} \ln X_{6}+\beta_{7} \ln X_{7}+d_{1} D_{M P}+d_{2} D_{H P}+d_{3} D_{\text {IRG }}+d_{4} D_{\text {SSN }}$ $+\mathrm{d}_{5} \mathrm{D}_{\mathrm{LOK}}+\left(v_{i}-u_{i}\right)$

With :

$\mathrm{Y}_{\mathrm{it}}=$ rice farm production i season $\mathrm{t}$ (kilogram)

$\mathrm{X}_{1}=$ land of rice farm $\mathrm{i}$ (meter square)

$\mathrm{X}_{2}=$ seeds of rice farm $\mathrm{i}$ (kilogram)

$\mathrm{X}_{3}=$ labor of rice farm $\mathrm{i}$ (equivalent 8 hours per day)

$\mathrm{X}_{4}=$ Phospate fertilizer of rice farm i (kilogram)

$\mathrm{X}_{5}=$ Organic fertilizer of rice farm i (kilogram)

$\mathrm{X}_{6}=$ Nitrogen fertilizer of rice farm $\mathrm{i}$ (kilogram)

$\mathrm{X}_{7}=$ Pesticide of rice farm $\mathrm{i}$ (liter)

$\mathrm{D}_{\mathrm{MP}}=$ dummy middle pollution $\left(\mathrm{D}_{\mathrm{MP}}=1\right.$ if the pollution is middle; $\mathrm{D}_{\mathrm{MP}}=0$ if others)

$D_{\mathrm{HP}}=$ dummy heavy pollution $\left(\mathrm{D}_{\mathrm{HP}}=1\right.$ if the pollution is heavy; $\mathrm{D}_{\mathrm{HP}}=0$ if others)

$D_{\text {IRG }}=$ dummy type of irrigation $\left(D_{\text {IRG }}=1\right.$ if the irrigation is technical type; $D_{\text {IRG }}=0$ if others)

$D_{\mathrm{SSN}}=$ dummy planting season $\left(\mathrm{D}_{\mathrm{SSN}}=1\right.$ rainy season; $\mathrm{D}_{\mathrm{SSN}}=$ 0 dry season)

$\mathrm{D}_{\mathrm{LOC}}=$ dummy location $\left(\mathrm{D}_{\mathrm{LOC}}=1\right.$ Sleman Regency; $\mathrm{D}_{\mathrm{LOC}}=0$ Bantul Regency)

$\mathrm{v}_{\mathrm{it}}=\mathrm{v}_{\mathrm{i}}$ random variable assumed as iid (identically independently distributed)

$\mathrm{u}_{\mathrm{it}}=\mathrm{u}_{\mathrm{i}}$ non-negative random variable assumed due to technical inefficiency in the production and also assumed as iid

$\beta_{1}, \ldots \beta_{7}=$ assumed function parameter

Reference [16] define that $u_{i t}$ is a componen of specific error term $\left(\varepsilon_{i t}\right)$, which $\varepsilon_{i t}=v_{i t}+u_{i t}$. Equation (2) is technical efficiency mesurement as in [17] and [18].

$T E=\frac{Y_{i}}{Y_{i^{*}}}=\frac{\mathrm{E}\left(Y_{i} \mid u_{i}, x_{i}\right)}{\mathrm{E}\left(Y_{i} \mid u_{i}=0, x_{i}\right)}=\mathrm{E}\left(\exp \left(-u_{i} \mid \varepsilon\right)\right.$

$\mathrm{i}=1,2.3, \ldots ., \mathrm{n}$
Where $\mathrm{Y}_{\mathrm{i}}$ is determenistic production function wich is production function without error term $\left(\mathrm{u}_{\mathrm{i}}\right)$. $\mathrm{U}_{\mathrm{i}}$ is a random variabel that describes technical inefficiency of farm assumed independent and normal distribution with $\mathrm{N}(\mu \mathrm{i}, \sigma 2)$. Reference [19], we can calculate Individualy technical efficiency of farm from ecpected value of $u_{i} \mid \varepsilon_{i}$.

$\mathrm{E}\left(\exp \left(-u_{i} \mid \varepsilon\right)=\frac{\sigma_{u} \sigma_{v}}{\sigma}\left|\frac{f\left(\frac{\varepsilon_{i}^{\lambda}}{\sigma}\right)}{1-F\left(\frac{\varepsilon_{i}^{\lambda}}{\delta}\right)}-\frac{\varepsilon_{i}^{\lambda}}{\sigma}\right| ; \mathrm{i}=1,2.3, \ldots, \mathrm{n}\right.$

$\mathrm{f}(\bullet)$ and $\mathrm{F}(\bullet)$ each is normal standart densitas function and normal standart distribution function. To analyze the influence of structural characteristic and managerial toward technical efficiency, the model was added with the variables of structural characteristic and managerial, so the equation that is inserted to production function and inefficiency effect becoming:

Ln $Y_{\text {it }}=\beta_{0}+\beta_{1} \ln X_{1}+\beta_{2} \ln X_{2}+\beta_{3} \ln X_{3}+\beta_{4} \ln X_{4}+\beta_{5} \ln X_{5}+$ $\beta_{6} \ln X_{6}+\beta_{7} \ln X_{7}++\delta_{0}+\delta_{1} Z_{1}+\delta_{2} Z_{2}+\delta_{3} Z_{3}+\delta_{4} Z_{4}+$ $\delta_{5} \mathrm{Z}_{5}+\delta_{6} \mathrm{Z}_{6}+\mathrm{d}_{1} \mathrm{D}_{\mathrm{MP}}+\mathrm{d}_{2} \mathrm{D}_{\mathrm{HP}}+\mathrm{d}_{3} \mathrm{D}_{\mathrm{IRG}}+\mathrm{d}_{4} \mathrm{D}_{\mathrm{SSN}}+$ $\mathrm{d}_{5} \mathrm{D}_{\text {LOC }}+\mathrm{d}_{6} \mathrm{D}_{\text {AREA }}+\mathrm{d}_{7} \mathrm{D}_{\text {OWN }}+\mathrm{d}_{8} \mathrm{D}_{\text {CRED }}+\mathrm{d}_{9} \mathrm{D}_{\text {PART }}+v_{i}$ $u_{i}$

With:

$\mathrm{Z}_{1}=$ farmer's age (year)

$\mathrm{Z}_{2}=$ farmer's education (score $:$ elementary $=1$; high school $=$ 2 ; high education $=3$ )

$\mathrm{Z}_{3}=$ farmer's experience (year)

$\mathrm{Z}_{4}=$ Family members (person)

$\mathrm{Z}_{5}=$ distance of irrigation sources (kilometer)

$\mathrm{Z}_{6}=$ non-farm income $(\mathrm{Rp})$

$\mathrm{D}_{\mathrm{AREA}}=$ dummy areas $\left(\mathrm{D}_{\mathrm{AREA}}=1\right.$ if it is in village areas; $\mathrm{D}_{\text {AREA }}=0$ if others)

Down $=$ dummy land ownership status $\left(\mathrm{D}_{\mathrm{OwN}}=1\right.$ if it is owning the land; $\mathrm{D}_{\mathrm{OwN}}=0$ if others)

$\mathrm{D}_{\mathrm{CRED}}=$ dummy access to credit $\left(\mathrm{D}_{\mathrm{RED}}=1\right.$ if there is access, $\mathrm{D}_{\mathrm{CRED}}=0$ if not)

$D_{\text {PART }}=$ dummy participation in group $\left(D_{\text {PART }}=1\right.$ if the farmers are active in groups, $\mathrm{D}=0$ if others)

Parameter assumption of production function and technical inefficiency function for rice based on the equation above simultaneously used Frontier 4.1 program [17]. Parameter testing of stochastic frontier and the effect of inefficiency was conducted in two stages. The first stage is the assumption of parameter $\delta_{\mathrm{i}}$ by using OLS method, while the second stage used Maximum Likelihood Estimator (MLE) test to estimate the assumption of the whole parameter $\delta_{i}$ (not $\delta_{0}$ ) and $\sigma_{\mathrm{i}}$ as well as variations $\mu_{\mathrm{i}}$ and $v_{i}$. The parameter of variations can estimate value $\gamma$, so the value $0 \leq \gamma \leq 1$. Value of $\gamma$ is the contribution of technical efficiency in total residual effect.

\section{RESULTS AND DISCUSSIONS}

\section{A. Production and Technical Efficiency of Rice Farm}

Based on the analysis of production function stochastic frontier model with Maximum Likelihood, it can be estimated the factors influencing the production as well as inefficiency effects and the value of rice farm production 
technical efficiency in Yogyakarta. Independent variables that are assumed to have significant influence toward rice production are the land, seeds usage, labor usage, fertilizer of Phosphate, Organic, and Nitrogen and pesticide. Table 1 presents completely description of the variables that are assumed to influence rice farm production.

Environmental factors assumed to have influence toward rice production are the level of irrigation pollution, type of irrigation, planting season, and the land location. Presentation of it in production function is in the form of dummy variables. The data of water irrigation pollution from Environmental Bureau of Yogyakarta Special Province is a calculation result of storet method. We made three categories of pollution level namely light pollution (score around 70-86), medium (score around 87-103) and severe (score around 104120).

Table 1. Descriptive Statistic of Varaible on Rice Farm Production in Yogyakarta

\begin{tabular}{|c|c|c|c|c|}
\hline Variables & Mean & Maximum & Minimum & Standard Deviation \\
\hline Production (kilogram) & $1,267.86$ & $3,700.00$ & 90.00 & 973.24 \\
\hline Land (meter square) & $2,458.88$ & $6,800.00$ & 180.00 & $1,768.66$ \\
\hline Seeds (kilogram) & 11.90 & 36.00 & 1.00 & 9.27 \\
\hline Labor (equal to 8 hours a day) & 7.95 & 48.50 & 0.01 & 6.79 \\
\hline Phosphate Fertilizer (kilogram) & 8.52 & 43.92 & 0.01 & 8.83 \\
\hline Organic Fertilizer (kilogram) & 140.70 & $2,000.00$ & 0.01 & 305.23 \\
\hline Nitrogen Fertilizer (kilogram) & 36.86 & 136.80 & 1.68 & 32.49 \\
\hline Pesticide (liter) & 0.80 & 3.00 & 0.01 & 0.93 \\
\hline Farmer's Age (year) & 57.96 & 78.00 & 32.00 & 0.67 \\
\hline Education (score) & 1.66 & 3.00 & 1.00 & 0.59 \\
\hline Experience (year) & 28.87 & 60.00 & 2.00 & 0.82 \\
\hline Family member (person) & 3.17 & 10.00 & 1.00 & 1.67 \\
\hline Distance of Irrigation source (kilometer) & 1.94 & 10.00 & 0.05 & 1.78 \\
\hline Non-farm Income (rupiah per month) & $1,314,088.00$ & $3,000,000.00$ & 0.00 & $2,829.00$ \\
\hline $\begin{array}{l}\text { Based on the estimation res } \\
\text { frontier production function (see table } \\
\text { parameter value } \gamma \text { with } 0.8177 \text {. Assum } \\
\text { the ratio between technical inefficien } \\
\text { toward the deviation that is probably } \\
\text { factors }\left(\mathrm{v}_{\mathrm{i}}\right) \text {. Statistically, value } 0.8177 \\
\text { of the error in production function }\end{array}$ & $\begin{array}{l}\text { of stochastic } \\
\text { this model has } \\
\text { parameter } \gamma \text { is } \\
\text { deviations }\left(u_{i}\right) \\
\text { sed by random } \\
\text { ans that } 81.77 \%\end{array}$ & \multicolumn{3}{|c|}{$\begin{array}{l}\text { existence of technical inefficiency, while the rest } \\
(18,23 \%) \text { is the variable of random error (risk). We can } \\
\text { assume that all the output variation of frontier } \\
\text { production is the effect of achievement level of } \\
\text { technical efficiency related to the managerial problem in } \\
\text { farm production management. The } \sigma^{2} \text { value shows } \\
\text { significant variations at the } 99 \% \text { confidence level. }\end{array}$} \\
\hline
\end{tabular}

production technical efficiency, or it is caused by the

Table 2. The Estimation of Rice Farm Production by Stochastic Frontier Production Function in Yogyakarta

\begin{tabular}{lcccr}
\hline \multicolumn{1}{c}{ Variables } & Parameter & Expected Sign & Coefficient & T-Ratio \\
\hline Production Function & & & & 0.2395 \\
Intercept & $\beta_{0}$ & $+/-$ & $0.9473 * * *$ & 1.1395 \\
Land & $\beta_{1}$ & + & -0.0311 & 32.1424 \\
Seed & $\beta_{2}$ & + & -0.0127 & 1.0723 \\
Labor & $\beta_{3}$ & + & -0.0022 & 1.4574 \\
Phosphate Fertilizer (P) & $\beta_{4}$ & + & 0.0028 & -0.4073 \\
Organic Fertilizer (O) & $\beta_{5}$ & + & 0.0346 & 1.2357 \\
Nitrogen Fertilizer (N) & $\beta_{6}$ & + & $0.0054 *$ & 1.3955 \\
Pesticide & $\beta_{7}$ & + & $-0.0599 *$ & 1.6576 \\
Dummy Medium Pollution & $\mathrm{d}_{1}$ & - & $-0.776^{*}$ & 1.6718 \\
Dummy Severe Pollution & $\mathrm{d}_{2}$ & - & $-0.1014 * * *$ & 1.7433 \\
Dummy Type of Irrigation & $\mathrm{d}_{3}$ & + & $-0.0884 * * *$ & 2.7204 \\
Dummy Planting Season & $\mathrm{d}_{4}$ & $+/-$ & $-0.1107 * * *$ & 3.4585 \\
Dummy Location & $\mathrm{d}_{5}$ & $+/-$ & $0.0717 * * *$ & 3.2982 \\
sigma-squared & $\sigma^{2}$ & & & 3.9980
\end{tabular}


Gamma

Log likelihood function

LR Test of the one-side error
0.8177

35.9306

51.838

$* * *)$ Means significantly different at the $99 \%$ confidence level

$* *$ ) Means significantly different at the $95 \%$ confidence level

*) Means significantly different at the $90 \%$ confidence level

The analysis result obtained likelihood ratio value (LR) with 51,838 more than chi-square value $\left(X^{2}\right.$-table $\alpha 1 \%$; with 26,217 ), so the independent variable has simultaneously influence toward dependent variables. Therefore, the land, numbers of labor, seeds, pesticide, Phosphate, Nitrogen and Organic fertilizer, and the level of irrigation pollution, type of irrigation, and dummy planting season and location simultaneously influenced toward rice farm production significantly.

Based on the result of independent variable used in the model of the production function, the variables which had a positive and significant influence to rice production are the land and pesticide. Dummy variables of pollution, type of irrigation, planting season, and location show significant influence toward rice production.

Based on the estimation result of production function by Stochastic Frontier, it obtained that the variable of the land had positive and significant influence with confidence level 99\% toward rice production. The coefficient value of land area variable in the model showed elasticity of land variable to rice production with 0.9473 . It means that the increase of area as much as one percent could increase rice production 0.9473 percent, cateris paribus. The condition explains that the land had positive correlation toward the width of harvest area, so it influenced the increase of rice production.

Due to rice production input, it showed that pesticide variable had a positive influence at the $90 \%$ confidence level toward rice production. It means that adding pesticide one percent would cause the increase of rice production 0.0054 percent, cateris paribus. On the other hand, the variables of using seeds input, family workers, fertilizer $\mathrm{P}$, organic fertilizer, and fertilizer $\mathrm{N}$ did not have significant influence toward rice production.

The environmental influence, especially in the level of contamination of irrigation water and weather has a significant effect toward rice production. Dummy variables of medium and severe pollution in irrigation water have a negatively significant effect at the confidence level of $90 \%$ to the rice farming production. It shows that there are differences in productivity between the middle and severe contamination level area with light pollution level. The rice production in the severe pollution level area is lower by 0.776 percent than the light contamination one. Meanwhile, if we compare it with medium contamination level, it was about -0.0599 percent lower than the rice production in light pollution level area. This condition shows that the higher the level of pollution, then the lower rice production will be.
Base on the observation, it shows that abaout 68 percent of the rice farms are in the middle and severe pollution area. Detailly, there are more than 50 percent $f$ them are in the severe pollution area.

Irrigation type variable has a negative and significant impact of $99 \%$ confidence level toward the rice farming production. It shows that there is a difference on productivity level between the area with technical and simple irrigation service. The rice production in the good irrigation water service area has 0.1014 percent lower than the rice production in the area with semi-technical or simple irrigation water service. However, most of the farming which has technical irrigation service $(73.5 \%)$ is located in the irrigation water flow with middle and severe contamination level. It indicates that environment has a dominant impact compared to the type of irrigation service toward rice productivity level.

Dummy variable planting season shows a significant difference in production between the rainy season to the dry season which at $99 \%$ confidence level. The coefficient of the dummy variable planting season on the model shows the difference in the magnitude of production amounted to 0.0884 percent lower during the rainy season compared to the production during the dry season. This difference occurred because during the rainy season there are kind of pests and plant diseases. In the rainy season proliferation of pests and plant diseases are relatively higher than in the dry season. It has a greater impact on the level of attack or interference plant growth and results in the production of rice farmers cultivated. Also, the drainage conditions work less optimally when flooding due to excessive rain. Both reasons are the cause of the decline in rice production during the rainy season.

Dummy variables in planting location showed a difference between the production in Bantul and Sleman District significantly at $99 \%$ confidence level. The coefficient of the dummy variable locations on the model shows much difference of rice production amounted to 0.1172 percent lower at Sleman than rice production in Bantul. This difference occurred because farm in Bantul district is in the areas that are relatively in lower elevation so that the irrigation needs is not mater. Also, the irrigation area in Bantul district is in the downstream areas are borne silt from upstream areas which allows its fertility levels relatively higher than Sleman.

Based on the technical efficiency analysis, the distribution data of rice farming technical efficiency shows that the majority value is around 0.70 up to 0.89 which there are 78 farmers $(62.4 \%)$ during the rainy season and 70 farmers $(56.0 \%)$ during the dry season. Meanwhile, there are $33(26.4 \%)$ farmers whose efficiency below 0.70 during the 
rainy season and 35 farmers $(28.0 \%)$. The average amount of technical efficiency farming is around 0.7615 . It shows that there is still a possibility to increase the amount of rice production up to $23.85 \%$ to reach maximum production. It is available at Table 3 .

\section{B. The Influence of Environmental and Managerial Factor toward Rice Farm Technical Efficiency}

The factors that influenced the level of the respondent technical efficiency farmers is analyzed using the method of technical inefficiency effect from stochastic frontier production function. Table 4 shows the result analysis of factors which influenced the technical efficiency level of rice farming in Yogyakarta.

Table 3. The Distribution of Technical Efficiency of Rice Farm Production

\begin{tabular}{|c|c|c|c|c|}
\hline \multirow{2}{*}{ Technical Efficiency (TE) } & \multicolumn{2}{|c|}{ Rainy Season } & \multicolumn{2}{|c|}{ Dry Season } \\
\hline & Number of Farmer & Percentage (\%) & Number of Farmer & Percentage (\%) \\
\hline $0,30-0,39$ & 1 & 0.8 & 1 & 0.8 \\
\hline $0,40-0,49$ & 3 & 2.4 & 4 & 3.2 \\
\hline $0,50-0,59$ & 9 & 7.2 & 12 & 9.6 \\
\hline $0,60-0,69$ & 20 & 16.0 & 18 & 14.4 \\
\hline $0,70-0,79$ & 37 & 29.6 & 31 & 24.8 \\
\hline $0,80-0,89$ & 41 & 32.8 & 39 & 31.2 \\
\hline $0,90-0,99$ & 14 & 11.2 & 20 & 16.0 \\
\hline Total & 125 & 100.0 & 125 & 100.0 \\
\hline Mean of TE & \multicolumn{2}{|c|}{0,763} & \multicolumn{2}{|c|}{0,760} \\
\hline Minimum TE & \multicolumn{2}{|c|}{0,391} & \multicolumn{2}{|c|}{0.390} \\
\hline Maximum TE & \multicolumn{2}{|c|}{0,954} & \multicolumn{2}{|c|}{0,955} \\
\hline
\end{tabular}

Table 4. The Influence of Environmental and Managerial Factor toward Rice Farm Technical Efficiency

\begin{tabular}{lcccc}
\hline \multicolumn{1}{c}{ Variables } & Parameter & Expectation Sign & Coefficient In-efficiency & T-Ratio \\
\hline Inefficiency Model & & & & \\
Intercept & $\delta_{0}$ & $+/-$ & 0.1141 & 0.4394 \\
Age & $\delta_{1}$ & $+/-$ & 0.0753 & 1.2288 \\
Education & $\delta_{2}$ & $+/-$ & -0.0448 & -0.8001 \\
Experience & $\delta_{3}$ & $+/-$ & $-0.0828^{*}$ & -1.8007 \\
Family member & $\delta_{4}$ & $+/-$ & 0.0068 & 0.3958 \\
Distance of irrigation & $\delta_{5}$ & $+/-$ & -0.0048 & -0.2386 \\
Non-farm income & $\delta_{6}$ & $+/-$ & $0.2-\mathrm{E} 07^{* *}$ & 2.4797 \\
Dummy areas & $\mathrm{d}_{1}$ & $+/-$ & $0.1544^{*}$ & 1.7631 \\
Dummy land status & $\mathrm{d}_{2}$ & $+/-$ & 0.0811 & 1.1057 \\
Dummy credit access & $\mathrm{d}_{3}$ & $+/-$ & $-0.1734^{* *}$ & -2.2157 \\
Dummy participation & $\mathrm{d}_{4}$ & $+/-$ & 0.0869 & 0.7886 \\
\hline
\end{tabular}

**) Means significantly different at the $95 \%$ confidence level

Based on the results of the technical inefficiency effects estimation model, it shows that farmer managerial characteristics factors that influence the efficiency of farming is their experience, off-farm income and access to credit. Variables of experience and access to credit negatively correlated significantly to technical inefficiency rice farming at $95 \%$ confidence level, while the off-farm income variable correlated positively and significantly related to the technical inefficiency rice farming at $95 \%$ confidence level.

Experience variable negative coefficient shows that the higher the experience of farmers, the lower technical inefficiency of farming they run. In other words, the more experienced, it is more efficient technically farming they run.

Dummy variable negative coefficient access to credit shows that rice farming that runs by the farmers whose access to credit has higher efficiency level compared to rice farming that runs by the farmers who has not the access to credit. The accessible credit could motivate them to develop their farm and a better expected result. Thus, the farm management will be more efficient than if they have access to credit.

Variable off-farm income and a dummy region correlated positively and significantly related to technical inefficiency rice farming at $95 \%$ confidence level. It means that the off-farm income positive effect on the technical 
inefficiency, which the higher off-farm income, the higher the level of inefficiency will be or level of lower rice farming technical efficiency. Conversely, the lower off-farm income, the higher the level of efficiency of rice farming will be. The off-farm income is related to the type of occupation and working hours of the off-farm. The off-farm actitity with higher incomes for farmers, will require more attention and the outpouring of work is relatively larger than farm activities. It allows farming is not treated as a priority work so that the management is less efficient.

Environmental factors that influence the technical efficiency of rice farming is agro-ecosystem condition of the area. The coefficient of the area dummy variable positive means farming which is in the rural areas have a higher level of inefficiency than the sub-urban areas. In other words, suburban farming is technically more efficient than farming in rural areas. Farmers in the sub-urban areas have relatively narrow land, or if it is large, the land ownership status is as cultivators or tenants. Also, the influence of the commercial mindset in the sub-urban area, the farm management will be relatively more efficient compared to farming in rural areas.

\section{CONCLUSION}

The rice production factors are the land, total pesticide, the level of irrigation pollution, type of irrigation, planting season, and location. Extending farm area and adding the total $\mathrm{N}$ fertilizer would increase rice production. Also, the level of irrigation pollution in middle level and severe level would decrease rice production. The rice production in good irrigation service area had lower production compared to rice production in simple irrigation area, and semi-technical irrigation system since the majority of good irrigation had middle and severe pollution. The difference between rice production in the rainy season and rice production in the dry season shows that the weather influence toward rice production. The rice production in the rainy season was lower than that in the dry season.

The mean of rice farm production technical efficiency was 0.7615 . It shows that there was still chance to increase rice production by 23.85 percent to reach maximum production. Based on the assumption result of the model of technical inefficiency effect, we can know that managerial factors that influenced technical efficiency were experience, access to credit, and non-farm income. The higher farmer's experience, the more efficient the production. Meanwhile, the availability of credit access could increase the technical efficiency of farm production. On the other hand, nonfarm income had opposite effect. The higher non-farm income, the production is more inefficient. Also, the environmental factor which had influence toward efficiency was dummy areas. The rice farm production in sub-urban area was more efficient than the rural area production.

It needs an extending the areas and preventing land conversing as an effort of increasing rice production. On the other hand, the effort to increase production through integrated pest control needs to concern on environmental quality by using natural pesticide and pest-predator.

The effort in improving rice farm production efficiency needs the increase of experience both in the form of skill and management capacity of the farmers. Providing financial for production could be done through credit facility. Besides, there should be an effort to repair the irrigation system facility as well as the quality of irrigation water, so the quantity and the quality of rice production can increase.

\section{ACKNOWLEDGMENT}

The authors acknowledge Supriyadi, Opralis, Habibullah, Imanuddin, Mahendra, Intan, Friska and Rezky for their assistance during field data collection.

\section{REFERENCES}

[1] Sherlund SM, Barrett CB, Adesina AA. Smallholder Technical Efficiency Controlling For Environmental Production Conditions. 2001 ;(February):

[2] Sharma KR, Pradhan NC, Leung P. Stochastic frontier approach to measuring irrigation performance : An application to rice production under the two systems in the Tarai of Nepal. Water Resources. 2009 ;37(7):2009-2018.

[3] Passel SV, Mathijs E, Huylenbroeck GV. Explaining Differences in Farm Sustainability : Evidence from Flemish Dairy farms. In: the International Association of Agricultural Economists Conference ,. Gold Coast, Australia: 2006. p. 1-16.

[4] Bravo-Ureta BE, Pinheiro AE. Technical, Economic, and Allocative Efficiency in Peasant Farming : Evidence From The Dominican RepublicC. The Developing Economics. 1997 ;35(1):48-67.

[5] Ahmad M, Chaudhry GM, Iqbal M. Wheat Productivity , Efficiency, and Sustainability : A Stochastic Production Frontier Analysis. The Pakistan Development Review. 2002 ;(Winter):643-663.

[6] Basnayake K, Gunaratne P. Estimation of Technical Efficiency and It $\mathrm{s}$ Determinants in the Tea Small Holding Sector in the Mid Country Wet Zone of Sri Lanka. $2002 ; 4137-150$.

[7] Tchale H, Sauer J. The efficiency of maize farming in Malawi . A bootstrapped translog frontier. 2007 ;

[8] Tchale H. The efficiency of smallholder agriculture in. AFJARE. 2009 ;3(2):101-121.

[9] Ceyhan V, with Bozoglu. Measuring the Technical Efficiency and Exploring the Inefficiency Determinant of Vegetable Farms in Samsung Province, Turkey. Agricultural Systems. 2007 ;94(3):649656.

[10] Kouser S, Mushtaq K, with Abedullah. Analysis of Technical Efficiency of Rice Production in Punjab (Pakistan) Implications for Future Investment Strategies. Pakistan Economics and Social Revew. $2007 ; 45(2): 231-244$.

[11] Msuya EE, Hisano S, Nairu T. Explaining Productivity Variation among Smallholder Maize Farmers in Tanzania. In: the XII World Congress of Rural Sociology of the International Rural Sociology Association. 2008. p. 1-34.

[12] Bakhsh K, Hassan S. Relationship between Technical Efficiency and Managerial Ability Evidence from Punjab, Pakistan [Internet]. 2008 ;Available from: http://www.wbiconpro.com/Management/411Bakhsh,L \& Hassan ,S. pdf

[13] Obare GA, Nyagaka DO, Nguyo W, Mwakubo SM. Are Kenya farmers allocatively efficient ? evidence from Irish Potato producers in Nyandarua North District Are Kenyan smallholders allocatively efficient ? Evidence from Irish potato producers in Nyandarua North district. Agricultural Economics. 2016 ;(November): 
[14] Hasan MK, Islam SMF. Technical Inefficiency of Wheat Production in Some Selected Areas of Bangladesh. Bangladesh Journal Agril. Res. $2010 ; 35$ (March):101-112.

[15] BPS. Statistik Indonesia. Jakarta: 2014.

[16] Aigner, C. D., K. Lovell, and P. Schmidt. 1977. Formulation and Estimation Stochastic Frontier Production Function Model. Journal of Economics 6. pp. $21-37$.

[17] Coelli T.J. A Guide to Frontier Version 4.1: A Computer Program for Stochastic Frontier Production and Cost Production Estimation. Production. $1996 ; 1-33$.

[18] Coelli T.J., D.S.P. Rao and G.E. Battese., 1998 An Introduction to Efficiency and Productivity Analysis, Kluwer-Nijhoff, Boston

[19] Jondrow, J., C.A Knox Lovell, Ivan S. Materov, dan Peter Schmidt. 1982. On The Estimation of Technical Inefficiency in the Stochastic Frontier production Function Model. Journal of Econometrics 19 (1982), 233-238. North Holland Publishing Company

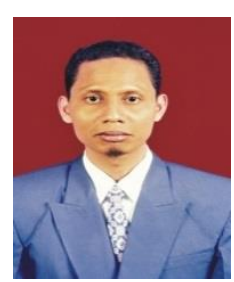

Author Profiles

Triyono received his B.Sc degree in Bachelor of Science in Agriculture, Gadjah Mada University, Indonesia in 1997. His Master degree in Agricultural Economics in Agricultural Faculty, Gadjah Mada University, Indonesia in 2004. Currently, He is studying his Ph.D. in Gadjah Mada University as well. He is a Lecturer at Universitas Muhammadiyah Yogyakarta, Indonesia. He has been working in this institution since 1999. His research interests include farm management, environmental and natural resources economics.

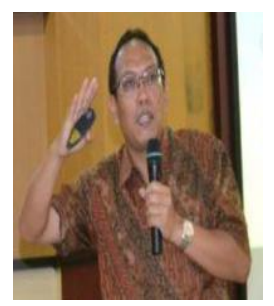

Jangkung Handoyo Mulyo is an associate professor and Head of Agricultural Socioeconomics Departement, Faculty of Agricultural Gadjah Mada University Indonesia. He received his B.Sc degree in Department of Agricultural Socioeconomics, Faculty of Agriculture, Gadjah Mada University, Indonesia in 1993. His Master degree in Department of Economic, Faculty of Business, Economics, and Law, The University of Queensland, Australia in 2000. He received his Ph.D. in Department of Economic Development and Policies, Graduate School of International Cooperation Studies, Kobe University, Japan in 2006. His research interests include food policy and agricultural economics.

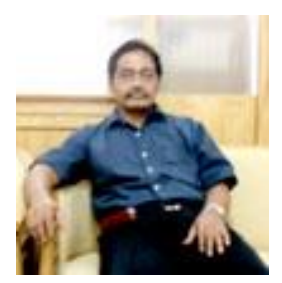

Masyhuri is a professor and lecturer in Agricultural Socioeconomics Departement, Faculty of Agricultural Gadjah Mada University
Indonesia. He received his B.Sc degree in Bachelor of Science in Agriculture, Gadjah Mada University, Indonesia in 1976. His Master degree in Agricultural Economics in Agricultural Faculty, Gadjah Mada University, Indonesia in 1979. He received his Ph.D. in Agricultural Economics, University of The Philippines at Los Banos, Philippines in 1988. His research interests include agribusiness and agricultural economics

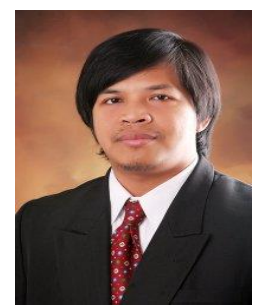

Jamhari is an associate professor and Dean of Agricultural Faculty Gadjah Mada University Indonesia. He received his B.Sc degree in Bachelor of Science in Agriculture, Gajah Mada University, Indonesia in 1995. His Master degree in Agricultural Economics in Agricultural Faculty, Gadjah Mada University, Indonesia in 1998. He received his Ph.D. in Tohuku University Japan. His research interests include agricultural cooperation and rural development. 
